\title{
Effect of different potassium levels in hay on acid-base status and mineral balance in periparturient dairy cows
}

\author{
M. Rérat, ${ }^{* 1}$ A. Philipp,${ }^{*} \dagger^{2}$ H. D. Hess, ${ }^{*}$ and A. Liesegang† \\ *Agroscope Liebefeld-Posieux Research Station ALP, PO Box 64, CH-1725 Posieux, Switzerland \\ †Institute of Animal Nutrition, Vetsuisse Faculty, University of Zurich, $\mathrm{CH}-8057$ Zurich, Switzerland
}

\begin{abstract}
Forages commonly used in dry cow rations contain high $\mathrm{K}$ concentrations. This results in a high dietary cation-anion difference (DCAD), which can compromise the calcium homeostasis of periparturient cows. The aim of this study was to determine the effect of 2 types of hay, fed during the prepartum period and differing in their $\mathrm{K}$ concentrations, on the peripartum acid-base status and mineral balance of dairy cows. During the prepartum period, the cows of group $\mathrm{K}_{33}$ (n $=6$ ) received a diet based on hay with a high $\mathrm{K}$ concentration $(33 \mathrm{~g} / \mathrm{kg}$ of DM), whereas the cows of group $\mathrm{K}_{13}(\mathrm{n}=6)$ received a diet based on hay with a low $\mathrm{K}$ concentration $(13 \mathrm{~g} / \mathrm{kg}$ of DM). Both experimental diets were formulated to be isoenergetic and isonitrogenous. After calving, all cows received the same diet based on hay $\mathrm{K}_{33}$. Blood and urine samples were taken on d 14, 7 , and 3 before parturition, at parturition, and then daily during the first $8 \mathrm{~d}$ after calving. Concentrations of minerals were analyzed in both blood and urine. Creatinine was also measured in urine for the calculation of the mineral:creatinine ratio. The acid-base parameters in blood ( $\mathrm{pH}$ and $\mathrm{HCO}_{3}{ }^{-}$concentration) and urine $(\mathrm{pH}$, net acid-base excretion, and base-acid quotient) were determined on $\mathrm{d} 14,7$, and 3 before parturition, at parturition, and on d 1 after parturition. The use of hay $\mathrm{K}_{13}$ reduced the DCAD value of the prepartum diet by half (195 vs. $514 \mathrm{mEq} / \mathrm{kg}$ of $\mathrm{DM})$. No significant differences between the 2 groups were observed for blood acid-base indicators or plasma minerals except for the $\mathrm{Mg}$ plasma concentration, which tended to be higher in group $\mathrm{K}_{13}$ from d 3 prepartum to d 2 after calving. In group $\mathrm{K}_{13}$, urinary Ca excretion tended to be higher from d 3 prepartum to $\mathrm{d} 1$ after parturition than that in group $\mathrm{K}_{33}$. On $\mathrm{d} 3$ before parturition, urinary $\mathrm{pH}$
\end{abstract}

Received June 3, 2009.

Accepted September 10, 2009.

${ }^{1}$ Corresponding author: michel.rerat@alp.admin.ch

${ }^{2}$ Part of a thesis for Dr. Med. Vet., accepted by Vetsuisse Faculty, University of Zurich, 2008. and net acid-base excretion were significantly lower in group $\mathrm{K}_{13}$ than in group $\mathrm{K}_{33}$. On $\mathrm{d} 14,7$, and 3 before parturition, base-acid quotient was significantly lower in group $\mathrm{K}_{13}$ than in group $\mathrm{K}_{33}$. In group $\mathrm{K}_{13}$, daily feed intake and hence daily intake of $\mathrm{Ca}, \mathrm{P}$, and $\mathrm{Mg}$ during $\mathrm{d}$ 3 and 4 after parturition were higher than in group $\mathrm{K}_{33}$. The decrease of the DCAD in positive ranges by feeding a low-K hay before parturition induced a reduction of the metabolic alkalotic charge, as observed in acid-base parameters in urine, and increased the availability of $\mathrm{Ca}$ and $\mathrm{P}$ as a result of higher feed intake at the onset of lactation.

Key words: potassium, dietary cation-anion difference, acid-base status, dairy cow

\section{INTRODUCTION}

For economical and ethical reasons, forage-based milk production systems are of increasing importance, particularly in organic production. Grass and grasslegume forages represent the principal feed source in these systems, where the fertilizer used is often based on organic manure. Because of its high $\mathrm{K}$ concentration, the use of slurry fertilizer leads to an enrichment of K in the soil (Soder and Stout, 2003) and this in turn results in high $\mathrm{K}$ concentrations in forage (ALP, 2008). Because dry cow rations are often exclusively based on forage, the dietary concentration of $\mathrm{K}$ during the prepartum period is generally high. These diets have a very high DCAD (Liesegang et al., 2007) and can compromise the calcium homeostasis of periparturient cows. Goff and Horst (1997) demonstrated that a high dietary concentration of strong cations, especially K, can induce metabolic alkalosis in the prepartum dairy cow, which reduces the ability of the cow to maintain Ca homeostasis. Whereas other minerals such as Ca, P, $\mathrm{Na}$, and $\mathrm{Cl}$ are usually supplemented with mineral feeds for adjustment of dietary imbalances, $\mathrm{K}$ is not usually added (Leiber et al., 2009). Consequently, different K concentrations in forage can influence the DCAD and mineral metabolism in dairy cows.

Some studies have been published on the effects of forages with contrasting DCAD on the acid-base status 
and mineral metabolism of periparturient dairy cows. The study of Delaquis and Block (1995) showed that a slight variation in positive DCAD affected acid-base status but not blood metabolites. The study of Roche et al. (2002) on cows grazing on pastures with altered K concentrations showed that the application of $\mathrm{K}$ fertilizer resulted in a DCAD ranging from 350 to $535 \mathrm{mEq} /$ $\mathrm{kg}$ of $\mathrm{DM}$, but that the Ca homeostasis in dairy cows was not changed. Charbonneau et al. (2008) reported that feeding low-DCAD timothy hay was an effective means of decreasing the DCAD of rations and obtaining a metabolic response in dry dairy cows. Because $\mathrm{K}$ is high in forage and is the major cation that determines the DCAD in this type of feed (Roche et al., 2002), further research is needed to determine how different natural $\mathrm{K}$ concentrations in prepartum diets may influence mineral homeostasis and acid-base status of periparturient dairy cows.

The aim of this experiment was to determine the effect of 2 types of hay, fed during the transition period and differing in their $\mathrm{K}$ concentration, on the peripartum mineral balance of dairy cows. In addition, indicators of acid-base changes in urine and blood were tested during the prepartum period to investigate their suitability as tools to detect early changes in acid-base status in the periparturient cow.

\section{MATERIALS AND METHODS}

\section{Design, Animals, and Feeds}

All procedures were in accordance with the Swiss guidelines for animal welfare and were approved by the Animal Care Committee of the Canton Fribourg, Switzerland. Sixteen cows (14 Holstein and 2 Brown Swiss), with 2 or more completed lactations and without antecedent episodes of clinical hypocalcemia, were selected for the trial and assigned to 2 diets based on hay with a natural $\mathrm{K}$ concentration of 13.4 (diet $\mathbf{K}_{13}$ ) or 33.0 (diet $\mathbf{K}_{33}$ ) g/ $\mathrm{kg}$ of DM. The cows were paired by breed, number of lactations (mean values $=3.2$ and 3.1 for groups $\mathrm{K}_{13}$ and $\mathrm{K}_{33}$, respectively), and milk production (mean values $=8,305 \pm 395$ and $7,976 \pm 373$ $\mathrm{kg}$ of milk yield after $305 \mathrm{~d}$ of lactation for groups $\mathrm{K}_{13}$ and $\mathrm{K}_{33}$, respectively). During the last 5 wk before the estimated calving ( $285 \mathrm{~d}$ of gestation), 1 cow from each pair was assigned to the experimental $\mathrm{K}_{13}$ regimen and the other assigned to the experimental $\mathrm{K}_{33}$ regimen. Cows were individually housed in a tie stall with rubber mat flooring during the prepartum period. After calving, all cows received the same dietary regimen and were kept in metabolism crates equipped with a slatted floor. The balance period lasted for $7 \times 24 \mathrm{~h}$ and began at $900 \mathrm{~h}$ on the day after calving (minimum $24 \mathrm{~h}$ and maximum $48 \mathrm{~h}$ after calving). Prior to the start of the balance period, cows were put in the metabolism crates for $1 \mathrm{~d}$ in order to get them accustomed to the crate.

During the prepartum period, the cows of experimental group $\mathrm{K}_{13}$ received $75 \mathrm{~g}$ of $\mathrm{DM} / \mathrm{kg}$ of $\mathrm{BW}^{0.75}$ of hay daily with a natural K concentration of $13.4 \mathrm{~g} / \mathrm{kg}$ of DM (Table 1). The hay was the first harvest from the previous year and was composed of $60 \%$ grasses and 15\% legumes. The grass was nonfertilized and floor dried. Additionally, cows were fed $7.5 \mathrm{~g}$ of DM/ $\mathrm{kg}$ of $\mathrm{BW}^{0.75}$ of a mineral- and protein-rich supplement containing $463 \mathrm{~g}$ of extracted rapeseed meal, $371 \mathrm{~g}$ of barley, $72 \mathrm{~g}$ of urea, $46 \mathrm{~g}$ of molasses, $23 \mathrm{~g}$ of ammonium phosphate, and $19 \mathrm{~g}$ of sodium phosphate per $\mathrm{kg}$ of DM. This supplement to the $\mathrm{K}_{13}$ diet was formulated to balance the low level of minerals (especially $\mathrm{Cl}$ and $\mathrm{P}$ ) and protein in $\mathrm{K}_{13}$ hay compared with $\mathrm{K}_{33}$ hay.

During the prepartum period, the cows of experimental group $\mathrm{K}_{33}$ were fed $75 \mathrm{~g}$ of $\mathrm{DM} / \mathrm{kg}$ of $\mathrm{BW}^{0.75}$ of hay daily with a natural $\mathrm{K}$ concentration of $33.0 \mathrm{~g} /$ $\mathrm{kg}$ of DM. The hay was the second harvest from $2 \mathrm{yr}$ previous and was composed of $72 \%$ grasses and $20 \%$ legumes. The grass had been fertilized first with ammonium nitrate and later with slurry.

Besides having a lower $\mathrm{K}$ concentration, the $\mathrm{K}_{13}$ hay also presented lower $\mathrm{S}$ and $\mathrm{Cl}$ concentrations than $\mathrm{K}_{33}$ hay. Nevertheless, the DCAD of $\mathrm{K}_{13}$ hay was only approximately half of the DCAD of $\mathrm{K}_{33}$ hay ( 228 vs. 544 $\mathrm{mEq} / \mathrm{kg}$ of DM).

In addition to hay, cows received $15 \mathrm{~g}$ of $\mathrm{NaCl}$ and $6 \mathrm{~g}$ of $\mathrm{MgO}$ daily. During the last 2 wk before calving, all cows received an increasing level of feed concentrate $\left(8,16\right.$, and $24 \mathrm{~g}$ of $\mathrm{DM} / \mathrm{kg}$ of $\mathrm{BW}^{0.75}$ on d 15 to 11,10 to 6 , and 5 to 1 before calving, respectively) containing $190 \mathrm{~g}$ of wheat, $250 \mathrm{~g}$ of maize, $230 \mathrm{~g}$ of barley, $190 \mathrm{~g}$ of soybean meal, $110 \mathrm{~g}$ of apple pomace, and $30 \mathrm{~g}$ of sugar beet pulp per $\mathrm{kg}$ (Table 2).

After calving, all cows were offered daily the $\mathrm{K}_{33}$ hay ad libitum, $32 \mathrm{~g}$ of $\mathrm{DM} / \mathrm{kg}$ of $\mathrm{BW}^{0.75}$ of the feed concentrate, and $2 \mathrm{~g}$ of $\mathrm{DM} / \mathrm{kg}$ of $\mathrm{BW}^{0.75}$ of a mineral mixture. The composition of the mineral mixture was $262 \mathrm{~g}$ of corn cube, $100 \mathrm{~g}$ of wheat bran, $170 \mathrm{~g}$ of $\mathrm{NaCl}, 50 \mathrm{~g}$ of calcium carbonate, $300 \mathrm{~g}$ of dicalcium phosphate, and $20 \mathrm{~g}$ of trace mineral mix $(1,300 \mathrm{mg}$ of $\mathrm{Zn}, 620 \mathrm{mg}$ of $\mathrm{Mn}, 160 \mathrm{mg}$ of $\mathrm{Cu}, 6.6 \mathrm{mg}$ of Se, and $3.3 \mathrm{mg}$ of $\mathrm{Co}$ ) per $\mathrm{kg}$ of DM.

The mineral- and protein-rich supplement, the mineral mixture, and the feed concentrate were mixed and provided as 2 equal meals at 0700 and $1630 \mathrm{~h}$ for 30 min, after which the feed was withdrawn. Throughout the experiment, cows had unlimited access to fresh water. 
Table 1. Composition of the diet components ${ }^{1}$

\begin{tabular}{|c|c|c|c|c|c|}
\hline Item & Hay $\mathrm{K}_{13}$ & Hay $\mathrm{K}_{33}$ & $\begin{array}{l}\text { Mineral- and protein- } \\
\text { rich supplement }\end{array}$ & $\begin{array}{l}\text { Mineral } \\
\text { mixture }\end{array}$ & $\begin{array}{c}\text { Feed } \\
\text { concentrate }\end{array}$ \\
\hline \multicolumn{6}{|l|}{ Ingredient, $\mathrm{g} / \mathrm{kg}$ of $\mathrm{DM}$} \\
\hline $\mathrm{DM}^{2}$ & 903 & 893 & 899 & 932 & 878 \\
\hline $\mathrm{CP}$ & 64 & 127 & 458 & 58 & 194 \\
\hline $\mathrm{NDF}$ & 596 & 525 & 218 & 149 & 218 \\
\hline $\mathrm{ADF}$ & 380 & 300 & 123 & 69 & 80 \\
\hline $\mathrm{ADL}^{3}$ & 57 & 35 & 47 & 18 & 21 \\
\hline $\mathrm{Ca}$ & 4.3 & 4.2 & 4.5 & 92.7 & 1.1 \\
\hline $\mathrm{P}$ & 1.7 & 3.8 & 18.6 & 62.6 & 4.4 \\
\hline $\mathrm{Mg}$ & 1.6 & 1.4 & 2.8 & 27.6 & 1.6 \\
\hline $\mathrm{Na}$ & 0.3 & 0.3 & 6.6 & 73.2 & 0.4 \\
\hline $\mathrm{K}$ & 13.4 & 33.0 & 10.6 & 4.3 & 9.7 \\
\hline $\mathrm{Cl}$ & 2.1 & 6.7 & 4.7 & 104.5 & 1.1 \\
\hline $\mathrm{S}$ & 1.1 & 2.0 & 4.3 & 1.2 & 2.1 \\
\hline \multicolumn{6}{|l|}{ Calculated concentration } \\
\hline $\mathrm{APD}_{2}^{4} \mathrm{~g} / \mathrm{kg}$ of $\mathrm{DM}$ & 63 & 87 & 105 & 39 & 130 \\
\hline $\mathrm{NE}_{\mathrm{L}},{ }^{5} \mathrm{MJ} / \mathrm{kg}$ of DM & 4.2 & 5.2 & 6.1 & 3.8 & 8.0 \\
\hline $\mathrm{DCAD},{ }^{6} \mathrm{mEq} / \mathrm{kg}$ of $\mathrm{DM}$ & 228 & 544 & 158 & 273 & 104 \\
\hline
\end{tabular}

${ }^{1} \mathrm{~K}_{13}=$ hay with a $\mathrm{K}$ concentration of $13 \mathrm{~g} / \mathrm{kg}$ of DM; $\mathrm{K}_{33}=$ hay with a $\mathrm{K}$ concentration of $33 \mathrm{~g} / \mathrm{kg}$ of DM.

${ }^{2}$ Grams per kilogram of wet weight.

${ }^{3} \mathrm{ADL}=$ acid detergent lignin.

${ }^{4} \mathrm{APD}=$ absorbable protein at the duodenum, according to ALP (2008).

${ }^{5}$ According to ALP (2008).

${ }^{6}$ According to Block (1984).

\section{Data Recording and Sample Collection}

Hays were sampled 5 times per week and pooled. The mineral- and protein-rich supplement, the mineral mixture, and the feed concentrate were sampled twice a week and pooled every 2 wk. During the prepartum period, the daily feed refusals were collected individually, stored at $-20^{\circ} \mathrm{C}$, and pooled together for analysis. During the balance period, hay, mineral mixtures, and feed concentrates were collected individually per cow and per day and the 7 daily samples were pooled. The refusals during the balance period were collected individually, stored at $-20^{\circ} \mathrm{C}$, and proportionally pooled. Feed intake was recorded daily.

Blood samples were taken between 1400 and $1500 \mathrm{~h}$ from the jugular vein with evacuated tubes, with and without heparin (Vacuettes; Greier Bio-one, Solingen, Germany) on d 14, 7, and 3 before the estimated calving, as well as at parturition, d 1 after parturition, and daily during the balance period (d 2-8 after parturition). Within $1 \mathrm{~h}$ after sampling, samples were centrifuged at $1,500 \times g$ for $15 \mathrm{~min}$. Plasma and serum were stored at $-20^{\circ} \mathrm{C}$. Additionally, tubes with EDTA were used for the determination of blood gases immediately after sampling on $\mathrm{d} 14,7$, and 3 before the estimated calving.

Urine samples were collected between 1400 and 1600 $\mathrm{h}$ on $\mathrm{d} 14,7$, and 3 before the estimated calving as well as at parturition and d 1 after parturition. Cows were manually stimulated to urinate and a sample of urine at midstream was collected. Within $1 \mathrm{~h}$ after collection, $\mathrm{pH}$ and the acid-base status parameters were measured. Urine samples were stored at $-20^{\circ} \mathrm{C}$ for mineral analysis. During the balance period [balance day (BD) 1-7], total amounts of urine and feces were recorded daily at $0900 \mathrm{~h}$ and samples were stored at $-20^{\circ} \mathrm{C}$. Urine was collected in plastic containers from a urinal that was attached around the vulva of the cow with Velcro tapes fixed to the shaved skin with instant glue (Cyanolit; 3M AG, Rüschlikon, Switzerland). Urine was collected without the addition of acid.

During the balance period, milk yields were determined at each milking (0500 and $1600 \mathrm{~h}$ ). Milk samples from both milkings of each $\mathrm{BD}$ were pooled proportionately and stored at $-20^{\circ} \mathrm{C}$ for mineral analysis.

\section{Laboratory Analysis}

Before laboratory analysis, feed samples and refusals were ground to pass a $1.0-\mathrm{mm}$ sieve (Brabender mill \#880804, Brabender, Duisburg, Germany). Contents of DM were quantified gravimetrically $\left(3 \mathrm{~h}\right.$ at $\left.105^{\circ} \mathrm{C}\right)$ and feces were quantified by freeze drying, milling, and subsequent heating at $105^{\circ} \mathrm{C}$ for $3 \mathrm{~h}$. Total ash was determined by incineration at $550^{\circ} \mathrm{C}$ for $4 \mathrm{~h}$. Cell wall constituents were analyzed using the Ankom 200/220 Fiber Analyzer (Ankom Technology Corporation, Fairport, NY). The ADF was analyzed according to AOAC (1995; method 973.18) and was expressed without residual ash after incineration at $500^{\circ} \mathrm{C}$ for $1 \mathrm{~h}$. 
Table 2. Composition of the experimental $\operatorname{diets}^{1}$

\begin{tabular}{|c|c|c|c|c|c|c|c|c|c|c|c|c|}
\hline \multirow[b]{3}{*}{ Item } & \multicolumn{4}{|c|}{ Days 15 to 11 prepartum $^{2}$} & \multicolumn{4}{|c|}{ Days 10 to 6 prepartum ${ }^{3}$} & \multicolumn{4}{|c|}{ Days 5 to 1 prepartum ${ }^{4}$} \\
\hline & \multicolumn{2}{|c|}{$\mathrm{K}_{13}$} & \multicolumn{2}{|c|}{$\mathrm{K}_{33}$} & \multicolumn{2}{|c|}{$\mathrm{K}_{13}$} & \multicolumn{2}{|c|}{$\mathrm{K}_{33}$} & \multicolumn{2}{|c|}{$\mathrm{K}_{13}$} & \multicolumn{2}{|c|}{$\mathrm{K}_{33}$} \\
\hline & $\begin{array}{l}\text { Per kg } \\
\text { of } \mathrm{BW}^{0.75}\end{array}$ & $\begin{array}{l}\text { Per kg } \\
\text { of DM }\end{array}$ & $\begin{array}{l}\text { Per kg } \\
\text { of } \mathrm{BW}^{0.75}\end{array}$ & $\begin{array}{l}\text { Per kg } \\
\text { of DM }\end{array}$ & $\begin{array}{l}\text { Per kg } \\
\text { of } \mathrm{BW}^{0.75}\end{array}$ & $\begin{array}{l}\text { Per kg } \\
\text { of DM }\end{array}$ & $\begin{array}{l}\text { Per kg } \\
\text { of } \mathrm{BW}^{0.75}\end{array}$ & $\begin{array}{l}\text { Per kg } \\
\text { of DM }\end{array}$ & $\begin{array}{l}\text { Per kg } \\
\text { of } \mathrm{BW}^{0.75}\end{array}$ & $\begin{array}{l}\text { Per kg } \\
\text { of DM }\end{array}$ & $\begin{array}{c}\text { Per kg } \\
\text { of } \mathrm{BW}^{0.75}\end{array}$ & $\begin{array}{l}\text { Per kg } \\
\text { of DM }\end{array}$ \\
\hline \multicolumn{13}{|l|}{ Ingredient } \\
\hline $\mathrm{CP}, \mathrm{g}$ & 9.8 & 108 & 11.1 & 133 & 11.4 & 115 & 12.6 & 139 & 12.9 & 121 & 14.2 & 143 \\
\hline NDF, $g$ & 48.1 & 531 & 41.1 & 495 & 49.8 & 506 & 42.9 & 470 & 51.6 & 484 & 44.6 & 450 \\
\hline $\mathrm{ADF}, \mathrm{g}$ & 30.1 & 332 & 23.1 & 278 & 30.7 & 312 & 23.8 & 261 & 31.3 & 294 & 24.4 & 246 \\
\hline $\mathrm{ADL},{ }^{5} \mathrm{~g}$ & 4.8 & 53.0 & 2.8 & 33.6 & 5.0 & 50.4 & 3.0 & 32.5 & 5.1 & 48.2 & 3.2 & 31.6 \\
\hline $\mathrm{Ca}, \mathrm{g}$ & 0.37 & 4.0 & 0.32 & 3.9 & 0.38 & 3.8 & 0.33 & 3.7 & 0.39 & 3.6 & 0.34 & 3.4 \\
\hline $\mathrm{P}, \mathrm{g}$ & 0.30 & 3.3 & 0.32 & 3.9 & 0.34 & 3.4 & 0.36 & 3.9 & 0.37 & 3.5 & 0.39 & 3.9 \\
\hline $\mathrm{Mg}, \mathrm{g}$ & 0.15 & 1.7 & 0.12 & 1.9 & 0.16 & 1.7 & 0.13 & 1.9 & 0.18 & 1.7 & 0.14 & 1.9 \\
\hline $\mathrm{Na}, \mathrm{g}$ & 0.07 & 0.8 & 0.03 & 0.9 & 0.08 & 0.8 & 0.03 & 0.9 & 0.08 & 0.8 & 0.03 & 0.8 \\
\hline $\mathrm{K}, \mathrm{g}$ & 1.16 & 12.8 & 2.55 & 30.7 & 1.24 & 12.6 & 2.63 & 28.9 & 1.31 & 12.4 & 2.71 & 27.3 \\
\hline $\mathrm{Cl}, \mathrm{g}$ & 0.2 & 2.2 & 0.51 & 6.8 & 0.21 & 2.1 & 0.52 & 6.3 & 0.22 & 2.1 & 0.53 & 5.9 \\
\hline $\mathrm{S}, \mathrm{g}$ & 0.13 & 1.5 & 0.17 & 2.0 & 0.15 & 1.5 & 0.18 & 2.0 & 0.17 & 1.6 & 0.2 & 2.0 \\
\hline \multicolumn{13}{|c|}{ Calculated concentration } \\
\hline $\mathrm{APD},{ }^{6} \mathrm{~g}$ & 6.6 & 72 & 7.6 & 91 & 7.6 & 77 & 8.6 & 94 & 8.6 & 81 & 9.7 & 97 \\
\hline $\mathrm{NE}_{\mathrm{L}},{ }^{7} \mathrm{MJ}$ & 0.42 & 4.7 & 0.45 & 5.5 & 0.49 & 5.0 & 0.52 & 5.7 & 0.55 & 5.2 & 0.58 & 5.9 \\
\hline $\mathrm{DCAD},{ }^{8} \mathrm{mEq}$ & & 211 & & 510 & & 203 & & 475 & & 195 & & 445 \\
\hline
\end{tabular}

${ }^{1} \mathrm{~K}_{13}=$ group receiving hay with a $\mathrm{K}$ concentration of $13 \mathrm{~g} / \mathrm{kg}$ of $\mathrm{DM} ; \mathrm{K}_{33}=$ group receiving hay with a $\mathrm{K}$ concentration of $33 \mathrm{~g} / \mathrm{kg}$ of $\mathrm{DM}$.

${ }^{2}$ Eight grams of DM feed concentrate $/ \mathrm{kg}$ of $\mathrm{BW}^{0.75}$.

${ }^{3}$ Sixteen grams of DM feed concentrate/ $\mathrm{kg}$ of $\mathrm{BW}^{0.75}$.

${ }^{4}$ Twenty-four grams of DM feed concentrate $/ \mathrm{kg}$ of $\mathrm{BW}^{0.75}$.

${ }^{5} \mathrm{ADL}=$ acid detergent lignin.

${ }^{6} \mathrm{APD}=$ absorbable protein at the duodenum, according to ALP (2008)

${ }^{7}$ According to ALP (2008).

${ }^{8}$ According to Block (1984)

(n) 
Analysis of NDF was based on the method of Mertens (2002) with the addition of heat-stable amylase and results were expressed without residual ash. Total N concentration of feeds, refusals, milk, and urine was analyzed by the Kjedahl procedure (method 988.05; AOAC, 1995). The CP concentration was calculated as $6.25 \times$ total $\mathrm{N}$ concentration. Levels of $\mathrm{Ca}, \mathrm{P}, \mathrm{Mg}, \mathrm{K}$, and $\mathrm{Na}$ were quantified in the incineration residues of feedstuffs, feces, and urine after solubilization in nitric acid $65 \%$ with an inductively coupled plasma optical emission spectrometer (Optima 2100 DV ICP-OES, PerkinElmer, Waltham, MA). The levels of $\mathrm{S}$ in feedstuffs were analyzed by infrared spectrometry (SC-432; Leco Corporation, St. Joseph, MI). After dilution in nitric acid, $\mathrm{Cl}$ concentrations in feedstuffs were determined by argentometrical titration using a Metrohm 716-titroprocessor (Herisau, Switzerland). Creatinine in urine was analyzed using an automatic analyzer (Cobas Mira, Roche, Basel, Switzerland). The urinary density was determined using a density meter (DMA 38; Anton Paar, Graz, Austria). For urine, $\mathrm{pH}$ was determined with a pH electrode (model 6.0202.10, Metrohm AG, Herisau, Switzerland) attached to a $\mathrm{pH}$ meter (EA 940, Orion, Cambridge, MA) and the fractionated net acid-base excretion (NABE) was analyzed by titration (665 Dosimat, Metrohm AG, Herisau, Switzerland) as described by Bender and Staufenbiel (2003). Urine titratable alkalinity was determined by titration of urine samples with $1 \mathrm{~N} \mathrm{HCl}$. Urine titratable acidity and ammonium concentrations were determined by titration of urine samples with $0.1 \mathrm{~N} \mathrm{NaOH}$.

The concentration of total $\mathrm{Ca}$ in blood plasma was measured using test kit \#1489216 from Roche; P and $\mathrm{Mg}$ levels were analyzed using test kits \#61571 and 61411, respectively, from BioMérieux (Marcy l'Etoile, France). An automatic analyzer was used for their analysis (Alizé 200, BioMérieux). An i-STAT portable clinical analyzer was used for the analyses of $\mathrm{pH}$ and $\mathrm{HCO}_{3}$ in whole blood (Abbott Point of Care Inc., East Windsor, NJ).

The levels of $\mathrm{Ca}, \mathrm{Mg}, \mathrm{K}$, and $\mathrm{Na}$ in milk were determined by atomic absorption spectrometry (Varian SpectrAA 800, Varian Inc., Palo Alto, CA). The level of $\mathrm{P}$ was determined by photometry (V530 photometer, Jasco, Tokyo, Japan).

\section{Calculations and Statistical Analysis}

The dietary concentrations of absorbable protein at the duodenum and $\mathrm{NE}_{\mathrm{L}}$ were calculated according to ALP (2008). The DCAD was calculated with the formula DCAD $(\mathrm{mEq} / \mathrm{kg}$ of $\mathrm{DM})=\left(\mathrm{Na}^{+}+\mathrm{K}^{+}\right)_{-}$ $\left(\mathrm{Cl}^{-}+\mathrm{S}^{2-}\right)$ (Block, 1984). The fractionated NABE was calculated with the formula $\mathrm{NABE}(\mathrm{mmol} / \mathrm{L})=$ urine base concentration - (urine acid concentration + ammonium concentration), and the base-acid quotient (BAQ) calculated with the formula BAQ $(\mathrm{mmol} / \mathrm{L})$ $=$ urine acid concentration/urine base concentration according to Bender and Staufenbiel (2003). For the analysis of the results, the times of sampling in relation to calving were calculated from the actual time of parturition and not from the estimated calving time.

Data were analyzed using the RANDOM and REPEATED methods of the MIXED procedure of NCSS 2000 (NCSS, Kaysville, UT). Group effects were tested using the Kruskall-Wallis test and the time effect was tested using the Wilcoxon-Rang test. Values were expressed as means \pm SEM; $P \leq 0.05$ was considered statistically significant.

\section{RESULTS}

\section{Animals and Feeds}

Of the 8 cows in each group at the beginning of the trial, 2 of the animals in group $K_{33}$ and 1 in group $\mathrm{K}_{13}$ suffered from clinical hypocalcemia and were excluded from the trial. One cow from group $K_{13}$ was recumbent on the day after calving and was treated for hypocalcemia. Although the pretreatment plasma Ca concentration was within the normal range, this cow was also excluded from the trial because of the intravenous Ca treatment. The mean DCAD values of the consumed prepartum $\mathrm{K}_{13}$ and $\mathrm{K}_{33}$ diets are shown in Table 3 . The daily feed intakes were similar $(P>0.05)$ in both groups during the prepartum period. Except for $\mathrm{Ca}$, the effective intake of nutrients was different $(P<0.001)$ between the 2 experimental groups during the prepartum period. The daily feed intake decreased $(P<0.05)$ in group $\mathrm{K}_{33}$ from d 2 prepartum to calving (Figure 1). After parturition, the daily feed intake in group $\mathrm{K}_{13}$ increased $(P<0.05)$ from d 2 to 4 and was higher $(P<0.05)$ than in group $\mathrm{K}_{33}$ on $\mathrm{d} 3$ and 4 . The mean daily feed intake and the effective intake of nutrients were similar $(P<0.05)$ during the balance period in both experimental groups (Table 3 ).

\section{Concentrations of Blood Parameters}

Plasma Ca concentrations declined $(P<0.05)$ from $\mathrm{d}$ 3 prepartum to 1 after calving in both groups (Figure $2)$. Calcium increased $(P<0.05)$ from d 1 to 5 after calving in group $\mathrm{K}_{13}$ and from d 1 to 8 after calving in group $\mathrm{K}_{33}$. In group $\mathrm{K}_{13}$, plasma $\mathrm{P}$ concentrations declined $(P<0.05)$ from d 3 prepartum to calving and increased $(P<0.05)$ from calving to $\mathrm{d} 4$ postpartum (Figure 3). In group $\mathrm{K}_{33}, \mathrm{P}$ increased $(P<0.05)$ from d 1 to 6 after calving. Plasma $\mathrm{Mg}$ concentrations in 


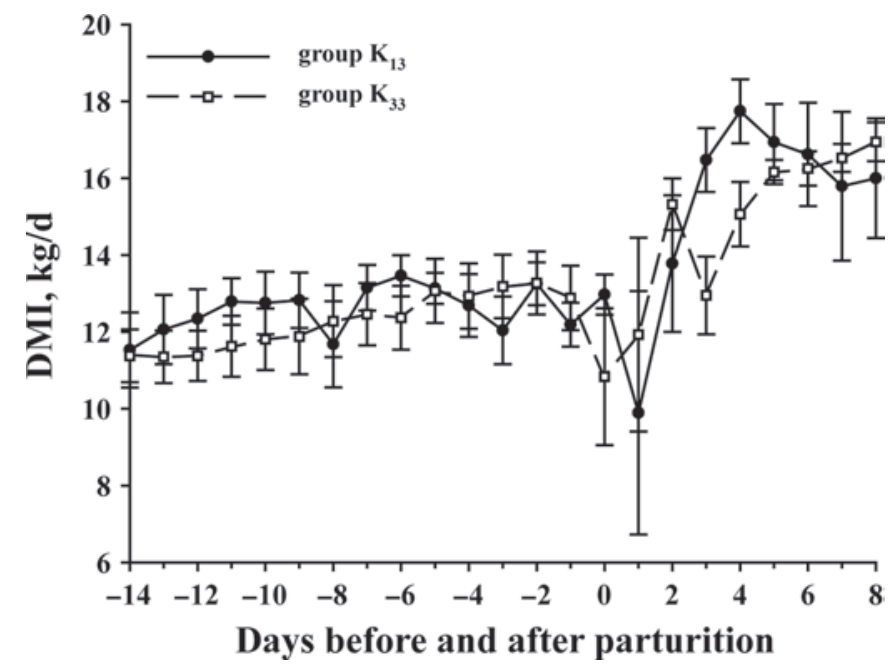

Figure 1. Variations in DMI for cows fed diets with different $\mathrm{K}$ levels in hay before parturition. Bars represent standard errors of the means. $\mathrm{K}_{13}$ and $\mathrm{K}_{33}=$ groups receiving hay with a $\mathrm{K}$ concentration of 13 or $33 \mathrm{~g} / \mathrm{kg}$ of $\mathrm{DM}$, respectively.

group $\mathrm{K}_{13}$ increased $(P<0.05)$ from d 3 prepartum to parturition (Figure 4). In both groups, $\mathrm{Mg}$ decreased $(P<0.05)$ from parturition to d 4 postpartum. No differences $(P>0.05)$ between the 2 groups were observed for plasma $\mathrm{Ca}$ and $\mathrm{P}$ during the entire experimental period. However, as is apparent in Figures 2 and 3, plasma $\mathrm{Ca}$ and $\mathrm{P}$ did return to normal values more rapidly in group $\mathrm{K}_{13}$ than they did in group $\mathrm{K}_{33}$. Plasma $\mathrm{Mg}$ tended to be higher $(P<0.1)$ in group $\mathrm{K}_{13}$ from d 3 prepartum to d 2 after calving. The mean $\mathrm{HCO}_{3}$ concentration $(27.3 \pm 1.1$ and $26.9 \pm 0.9 \mathrm{mmol} / \mathrm{L}$ for

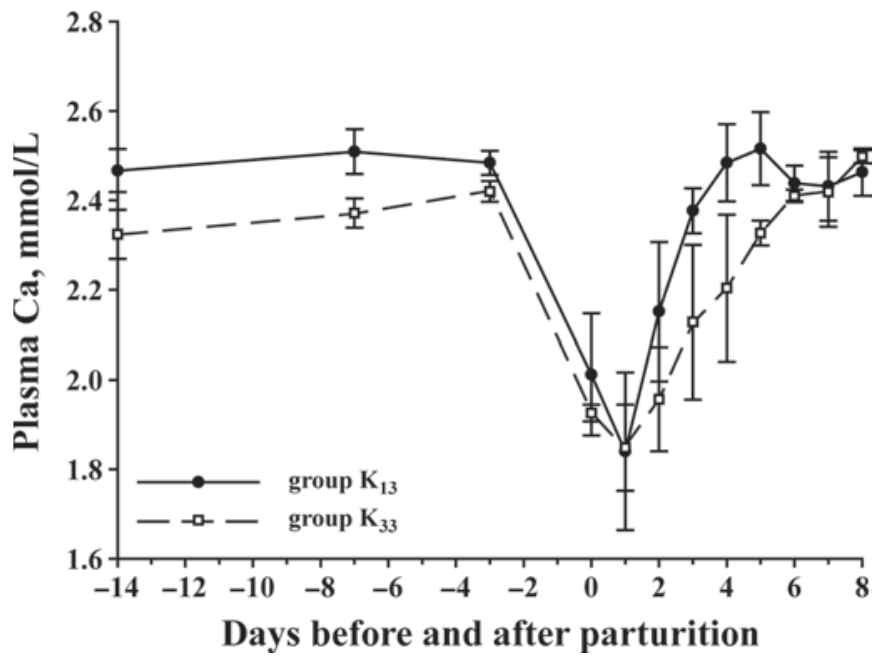

Figure 2. Profiles of mean serum Ca concentrations in cows fed diets with different $\mathrm{K}$ levels in hay before parturition. Bars represent standard errors of the means. $\mathrm{K}_{13}$ and $\mathrm{K}_{33}$ = groups receiving hay with a K concentration of 13 or $33 \mathrm{~g} / \mathrm{kg}$ of DM, respectively.

groups $\mathrm{K}_{13}$ and $\mathrm{K}_{33}$, respectively) and $\mathrm{pH}(7.38 \pm 0.02$ and $7.39 \pm 0.02$ for groups $\mathrm{K}_{33}$ and $\mathrm{K}_{13}$, respectively) in blood were similar $(P>0.05)$ in both groups.

\section{Concentrations of Urinary Parameters}

Because excretion of creatinine is relatively constant (Albin and Clanton, 1966), the urine creatinine concentration was used as an index to estimate excretion of minerals in urine. The expression of urine minerals as a mineral:creatinine ratio overcomes variations in

Table 3. Effective nutrient intake during the prepartum and balance periods of cows fed diets with different $\mathrm{K}$ levels in hay ${ }^{1}$

\begin{tabular}{|c|c|c|c|c|c|c|c|c|}
\hline \multirow[b]{2}{*}{ Item } & \multicolumn{4}{|c|}{ Prepartum diet } & \multicolumn{4}{|c|}{ Balance period } \\
\hline & $\mathrm{K}_{13}$ & $\mathrm{~K}_{33}$ & SEM & $P$-value & $\mathrm{K}_{13}$ & $\mathrm{~K}_{33}$ & SEM & $P$-value \\
\hline $\mathrm{DMI}, \mathrm{kg} / \mathrm{d}$ & 12.6 & 12.3 & 0.19 & 0.295 & 16.2 & 15.6 & 0.45 & 0.488 \\
\hline \multicolumn{9}{|l|}{ Ingredient, $\mathrm{g} / \mathrm{d}$} \\
\hline $\mathrm{Ca}$ & 47.3 & 48.2 & 0.72 & 0.418 & 74.6 & 71.4 & 2.00 & 0.287 \\
\hline $\mathrm{P}$ & 41.4 & 48.6 & 0.98 & $<0.001$ & 78.6 & 75.9 & 1.94 & 0.386 \\
\hline $\mathrm{Mg}$ & 20.5 & 23.4 & 0.33 & $<0.001$ & 29.0 & 28.3 & 0.75 & 0.516 \\
\hline $\mathrm{Na}$ & 9.1 & 11.2 & 0.19 & $<0.001$ & 23.9 & 22.4 & 0.84 & 0.221 \\
\hline K & 158 & 371 & 3.0 & $<0.001$ & 409 & 405 & 14.0 & 0.831 \\
\hline $\mathrm{Cl}$ & 29.3 & 80.7 & 0.57 & $<0.001$ & 109 & 106 & 4.0 & 0.567 \\
\hline $\mathrm{S}$ & 18.5 & 23.1 & 0.44 & $<0.001$ & 33.1 & 32.0 & 0.88 & 0.387 \\
\hline \multicolumn{9}{|l|}{ Calculated values } \\
\hline $\mathrm{APD}_{2}^{2} \mathrm{~g} / \mathrm{d}$ & 1,017 & 1,168 & 18.3 & $<0.001$ & 1,535 & 1,469 & 45.2 & 0.318 \\
\hline $\mathrm{NE}_{\mathrm{L}},{ }^{3} \mathrm{MJ} / \mathrm{d}$ & 66.0 & 74.3 & 0.96 & $<0.001$ & 76.5 & 72.2 & 2.49 & 0.256 \\
\hline $\mathrm{DCAD},{ }^{4} \mathrm{mEq} / \mathrm{d}$ & 195 & 514 & 4.9 & $<0.001$ & 393 & 407 & 4.8 & 0.384 \\
\hline
\end{tabular}

${ }^{1} \mathrm{~K}_{13}$ = group receiving hay with a $\mathrm{K}$ concentration of $13 \mathrm{~g} / \mathrm{kg}$ of $\mathrm{DM} ; \mathrm{K}_{33}$ = group receiving hay with a $\mathrm{K}$ concentration of $33 \mathrm{~g} / \mathrm{kg}$ of DM.

${ }^{2} \mathrm{APD}=$ absorbable protein at the duodenum, according to ALP (2008).

${ }^{3}$ According to ALP (2008).

${ }^{4}$ According to Block (1984). 


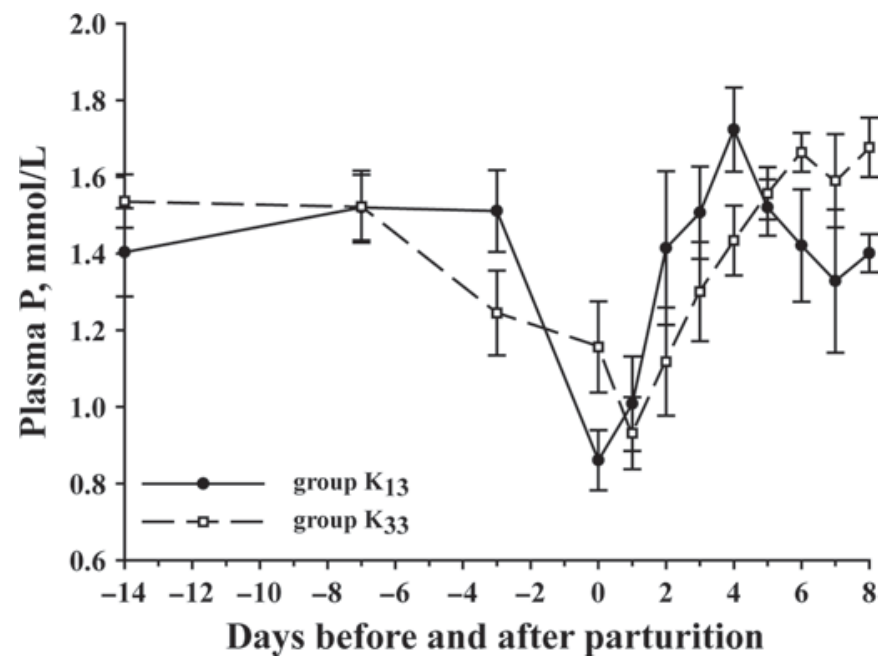

Figure 3. Profiles of mean serum $\mathrm{P}$ concentrations in cows fed diets with different $\mathrm{K}$ levels in hay before parturition. Bars represent standard errors of the means. $\mathrm{K}_{13}$ and $\mathrm{K}_{33}=$ groups receiving hay with a K concentration of 13 or $33 \mathrm{~g} / \mathrm{kg}$ of $\mathrm{DM}$, respectively.

urine volume among animals. Urinary $\mathrm{Ca}$ excretion in group $\mathrm{K}_{13}$ increased $(P<0.05)$ during the first $24 \mathrm{~h}$ after calving, from $0.006 \mathrm{mmol} / \mathrm{mmol}$ of creatinine at calving to $0.008 \pm 0.003$ at $\mathrm{d} 1$ postpartum. Urinary concentrations of $\mathrm{Ca}$ in group $\mathrm{K}_{13}$ tended to be higher $(P<0.1)$ from d 3 prepartum to d 1 after calving than they were in group $K_{33}$ (mean values $=0.009 \pm 0.003$ and $0.005 \pm 0.001 \mathrm{mmol} / \mathrm{mmol}$ of creatinine for groups $\mathrm{K}_{13}$ and $\mathrm{K}_{33}$, respectively). The urinary $\mathrm{P}$ excretion in both experimental groups remained unchanged (mean values $=0.031 \pm 0.007$ and $0.031 \pm 0.001 \mathrm{mmol} / \mathrm{mmol}$

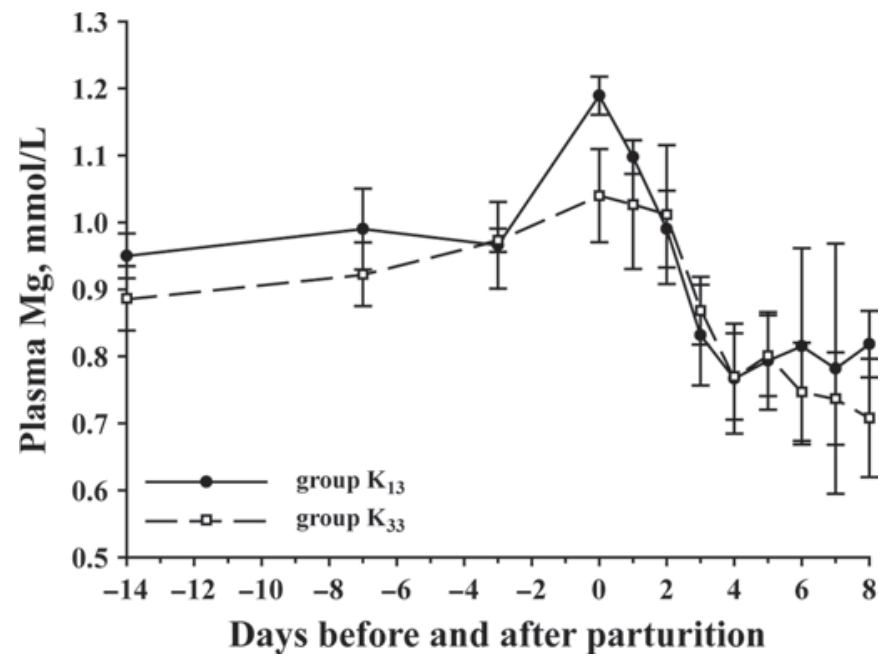

Figure 4. Profiles of mean serum $\mathrm{Mg}$ concentrations in cows fed diets with different $\mathrm{K}$ levels in hay before parturition. Bars represent standard errors of the means. $\mathrm{K}_{13}$ and $\mathrm{K}_{33}=$ groups receiving hay with a K concentration of 13 or $33 \mathrm{~g} / \mathrm{kg}$ of DM, respectively. of creatinine for groups $\mathrm{K}_{13}$ and $\mathrm{K}_{33}$, respectively) and was not affected by experimental treatment. Urinary $\mathrm{Mg}$ excretion was higher $(P<0.001)$ in group $\mathrm{K}_{13}$ than in group $\mathrm{K}_{33}$ from d 14 prepartum to d 1 after calving (mean values $=0.49 \pm 0.14$ and $0.21 \pm 0.06 \mathrm{mmol} /$ mmol of creatinine for groups $\mathrm{K}_{13}$ and $\mathrm{K}_{33}$, respectively). Urine $\mathrm{pH}$ and $\mathrm{NABE}$ were significantly lower in group $\mathrm{K}_{13}$ than in group $\mathrm{K}_{33}$ on d 3 prepartum (Figures 5 and $6)$. During the first $24 \mathrm{~h}$ after calving, NABE increased $(P<0.05)$ in group $\mathrm{K}_{13}$. During the entire prepartum period, the BAQ values were significantly lower $(P<$ 0.05) in group $K_{13}$ than in group $K_{33}$ (Figure 7 ).

\section{Balance Period}

The daily intakes of $\mathrm{DM}$ and $\mathrm{Ca}, \mathrm{P}$, and $\mathrm{Mg}$ in group $\mathrm{K}_{13}$ on BD 2 and 3 were higher $(P<0.05)$ than in group $\mathrm{K}_{33}$ (Table 4). The urinary excretion of $\mathrm{Mg}$ during the entire balance period was higher $(P<0.05)$ in group $\mathrm{K}_{13}$ than in group $\mathrm{K}_{33}$ and urinary $\mathrm{Na}$ excretion was higher $(P<0.05)$ on BD 3 in group $\mathrm{K}_{13}$ than in group $\mathrm{K}_{33}$. The retention of $\mathrm{Mg}$ on $\mathrm{BD} 1$ was more negative $(P<0.05)$ in group $\mathrm{K}_{13}$ than in group $\mathrm{K}_{33}$ and on $\mathrm{BD}$ 3 the retentions of $\mathrm{Ca}$ and $\mathrm{P}$ in group $\mathrm{K}_{13}$ were higher $(P<0.05)$ than in group $\mathrm{K}_{33}$.

\section{DISCUSSION}

\section{Effect of Different K Concentrations in the Prepartum Diet on DCAD}

Feed refusals were higher in group $\mathrm{K}_{13}$, particularly the mineral- and protein-rich supplements. Consequent-

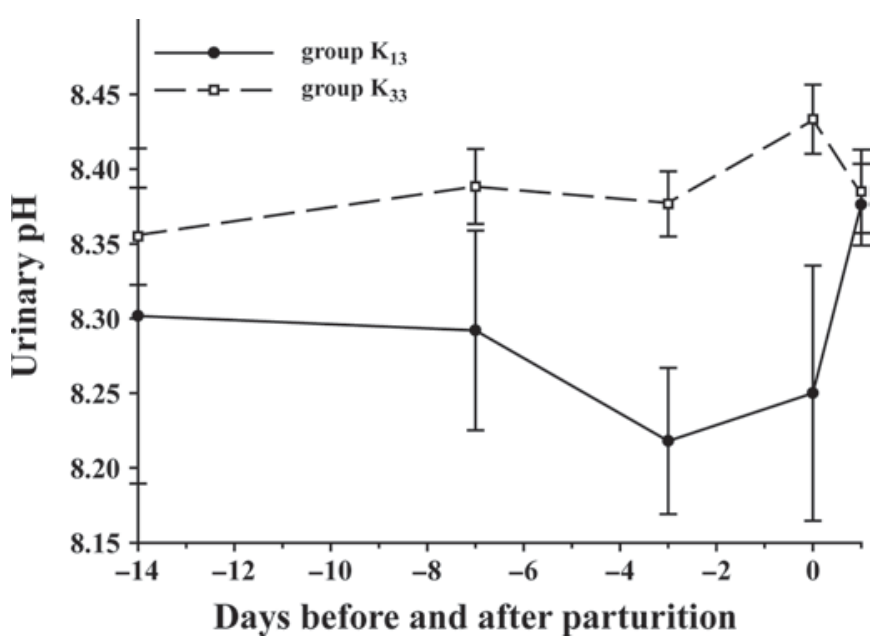

Figure 5. Profiles of mean urinary $\mathrm{pH}$ in cows fed diets with different $\mathrm{K}$ levels in hay before parturition. Bars represent standard errors of the means. $\mathrm{K}_{13}$ and $\mathrm{K}_{33}$ = groups receiving hay with a $\mathrm{K}$ concentration of 13 or $33 \mathrm{~g} / \mathrm{kg}$ of $\mathrm{DM}$, respectively. 


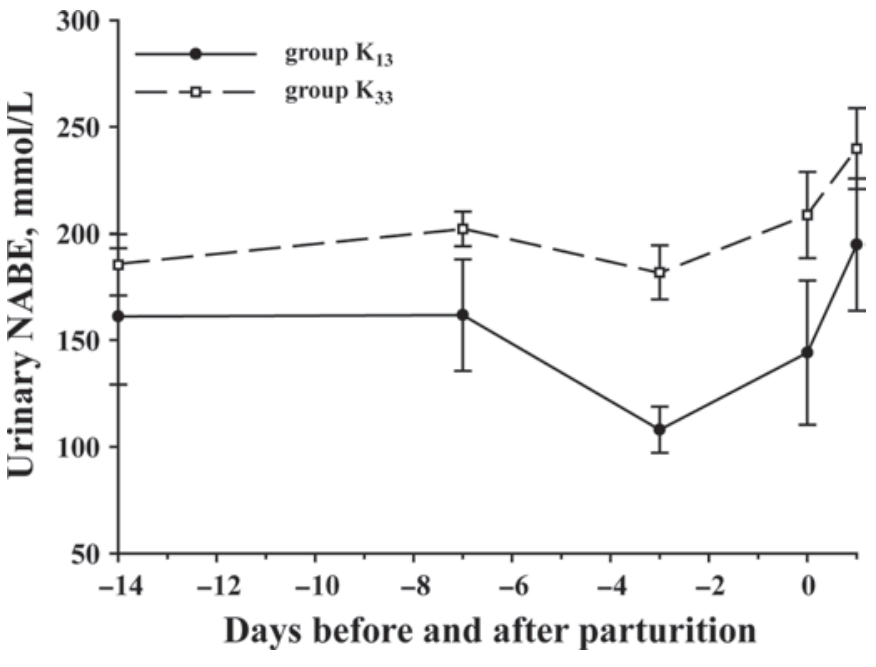

Figure 6. Profiles of mean urinary net acid-base excretion (NABE) in cows fed diets with different $\mathrm{K}$ levels in hay before parturition. Bars represent standard errors of the means. $\mathrm{K}_{13}$ and $\mathrm{K}_{33}$ = groups receiving hay with a $\mathrm{K}$ concentration of 13 or $33 \mathrm{~g} / \mathrm{kg}$ of DM, respectively.

ly, the effective intake of energy, protein, and minerals (especially $\mathrm{Cl}$ ) in group $\mathrm{K}_{13}$ was lower. In addition, a decrease in the $\mathrm{K}$ concentration in plants is accompanied by a decrease in the concentration of $\mathrm{Cl}$ (Roche et al., 2000). Chloride is a strong anion and has an important influence on DCAD (Goff, 2000). Despite this, the differences in DCAD between diets $\mathrm{K}_{13}$ and $\mathrm{K}_{33}$ were large (195 vs. $514 \mathrm{mEq} / \mathrm{kg}$ of $\mathrm{DM}$ ), but the DCAD of diet $\mathrm{K}_{13}$ was not sufficiently low to induce metabolic acidosis. This is in accordance with the findings of Roche et al. (2002), who reported that DCAD levels of 140 to 200 $\mathrm{mEq} / \mathrm{kg}$ of DM were not sufficient to reduce systemic $\mathrm{pH}$. Ions like $\mathrm{Na}, \mathrm{Cl}$, and $\mathrm{S}$ are present in relatively low amounts in forage and are not as relevant as is $\mathrm{K}$ in the determination of DCAD (Roche et al., 2002). Despite a significantly lower daily intake of $\mathrm{P}, \mathrm{Mg}, \mathrm{Na}, \mathrm{Cl}$, and $\mathrm{S}$ in group $\mathrm{K}_{13}$, the observed reduction in the DCAD was primarily caused by the difference in $\mathrm{K}$ concentration in the 2 hays. In conclusion, it was possible to reduce the DCAD value of the prepartum diet by half by using hay with a low $\mathrm{K}$ concentration.

\section{Effect of Different $K$ Concentrations in the Prepartum Diet on DMI and Mineral Balance of Periparturient Cows}

Lowering DCAD in nonlactating cows may decrease DMI, as demonstrated by the meta-analysis of Charbonneau et al. (2006). The usual method is to add anionic salts, which can drastically reduce the DCAD but also reduce the palatability of the diet (Vagnoni and Oetzel, 1998). A more moderate reduction of the DCAD values of prepartum diets by feeding forages with low $\mathrm{K}$ concentration, as tested in the present study, would seem to avoid this problem and may still have some positive effects on mineral balance. In contrast to the data presented by Roche et al. (2002), in the current study, a diet with a DCAD of approximately $200 \mathrm{mEq} /$ $\mathrm{kg}$ of DM tended to increase the peripartum urine $\mathrm{Ca}$ concentration. This could indicate an increased intestinal absorption, increased bone resorption, or a reduced renal reabsorption even though plasma Ca concentration was unaffected (Roche et al., 2002). Tucker et al. (1992) explained that an increase in urinary Ca excretion typically represents an increased availability of $\mathrm{Ca}$ for metabolic functions and may be a useful measure for evaluating Ca status.

In the present study, the prepartum urinary excretion of $\mathrm{Mg}$ in group $\mathrm{K}_{13}$ may have been increased by the lower dietary $\mathrm{K}$ concentration, and hence by a decreased DCAD, in agreement with earlier studies (Gaynor et al., 1989; Roche et al., 2002). The negative interaction between ruminal $\mathrm{K}$ concentration and $\mathrm{Mg}$ absorption (Martens and Schweigel, 2000) can explain the absence of increased $\mathrm{Mg}$ levels at calving in the blood of cows receiving the high- $\mathrm{K}$ diet. Regardless of dietary $\mathrm{K}$, the increase in the concentration of plasma $\mathrm{Mg}$ at calving is probably the result of enhanced renal $\mathrm{Mg}$ absorption (Goff and Horst, 1997). The lower Mg concentrations in group $\mathrm{K}_{33}$ from d 3 prepartum to d 2 after calving could be explained by the interference of high dietary $\mathrm{K}$ with ruminal absorption of $\mathrm{Mg}$ (Schonewille et al., 1997).

Further effects of feeding the low-K hay were also observed after calving. The daily feed intake in group

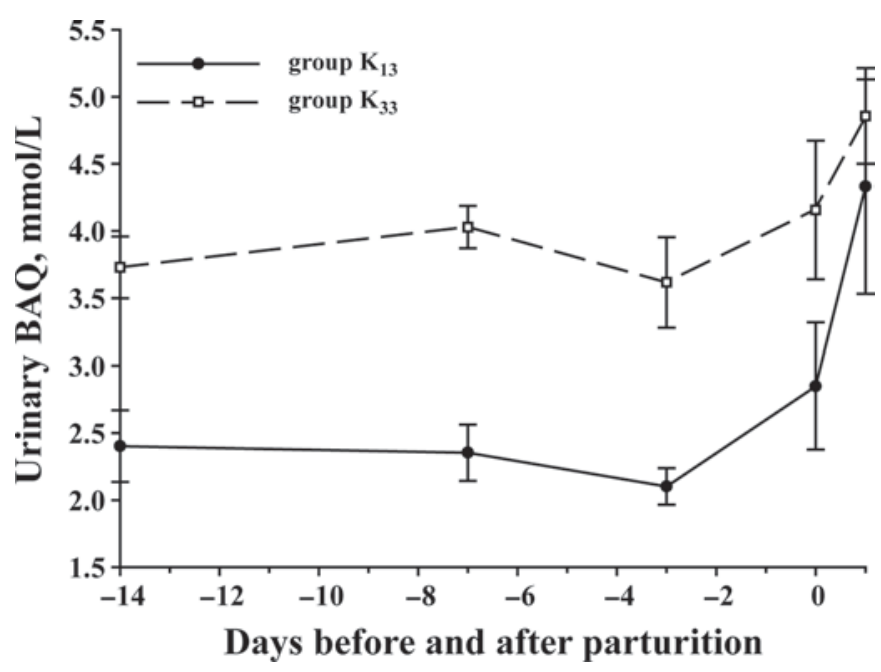

Figure 7. Profiles of mean urinary base-acid quotient (BAQ) in cows fed diets with different $\mathrm{K}$ levels in hay before parturition. Bars represent standard errors of the means. $\mathrm{K}_{13}$ and $\mathrm{K}_{33}=$ groups receiving hay with a K concentration of 13 or $33 \mathrm{~g} / \mathrm{kg}$ of DM, respectively. 
$\mathrm{K}_{13}$ during BD 2 and 3 was higher, which had a positive effect on the $\mathrm{Ca}$ and $\mathrm{P}$ balances during the first days after parturition. Because of the higher DMI during BD 2 and 3, daily intake of $\mathrm{Ca}, \mathrm{P}$, and $\mathrm{Mg}$ in group $\mathrm{K}_{13}$ increased. The excretion of these minerals was similar in both experimental groups, except for a slightly higher urinary $\mathrm{Mg}$ excretion in group $\mathrm{K}_{13}$. This resulted in an increased retention of $\mathrm{Ca}$ and $\mathrm{P}$ on $\mathrm{BD} 3$. Thus, the increased availability of $\mathrm{Ca}$ and $\mathrm{P}$ during the first days after parturition may have contributed to the faster return of plasma $\mathrm{Ca}$ and $\mathrm{P}$ to normal levels in group $\mathrm{K}_{13}$. These results indicate that a moderate reduction

Table 4. Daily intake of $\mathrm{DM}, \mathrm{Ca}, \mathrm{P}, \mathrm{Mg}, \mathrm{K}$, and $\mathrm{Na}$ and urine excretion and retention of $\mathrm{Ca}, \mathrm{P}, \mathrm{Mg}, \mathrm{K}$, and Na during the balance period of cows fed diets with different $\mathrm{K}$ levels in hay ${ }^{1}$

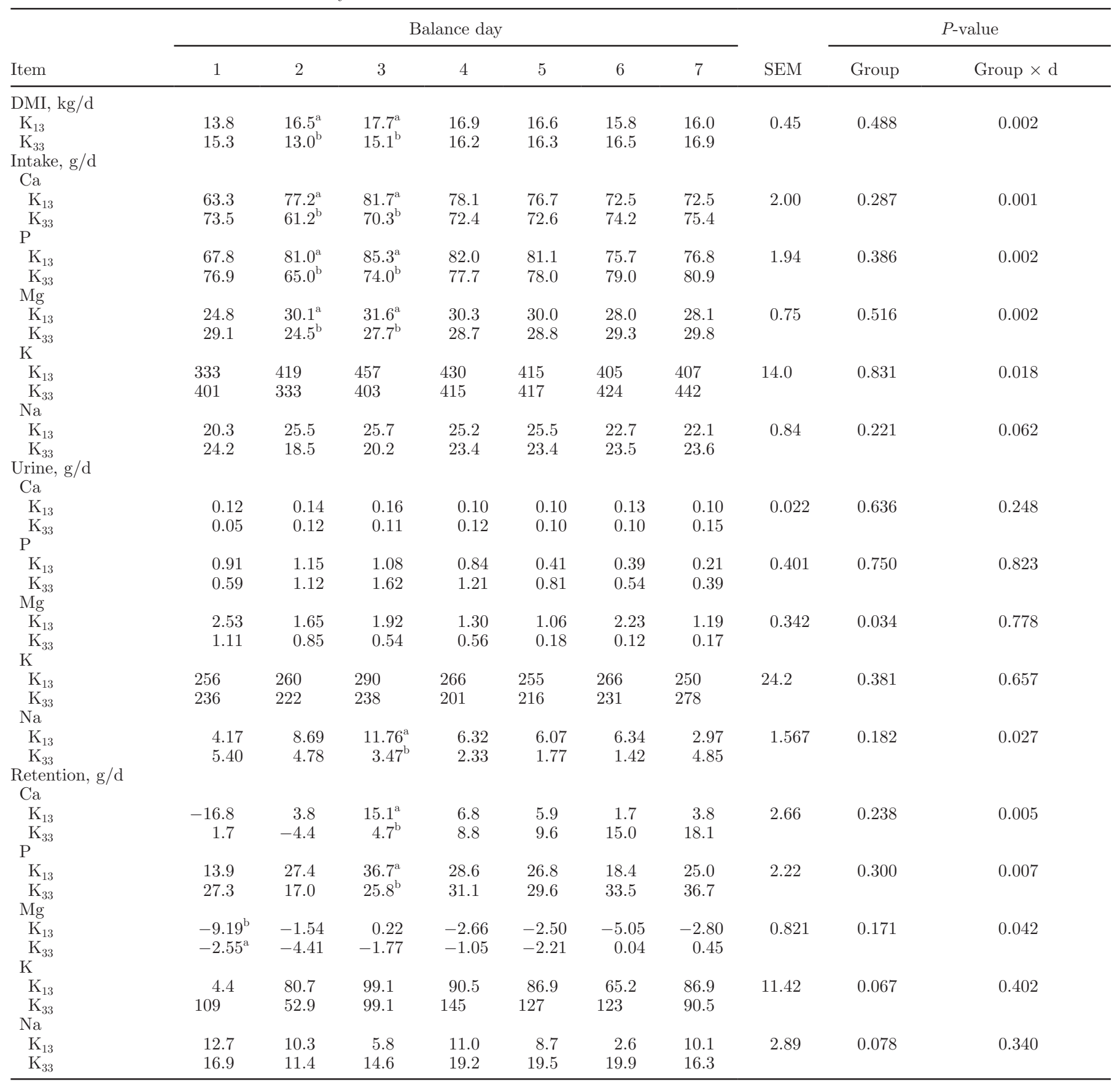

${ }^{\mathrm{a}, \mathrm{b}}$ Means of groups $\mathrm{K}_{13}$ and $\mathrm{K}_{33}$ at the same balance day with different superscripts differ $(P<0.05)$.

${ }^{1} \mathrm{~K}_{13}=$ group receiving hay with a $\mathrm{K}$ concentration of $13 \mathrm{~g} / \mathrm{kg}$ of DM; $\mathrm{K}_{33}=$ group receiving hay with a $\mathrm{K}$ concentration of $33 \mathrm{~g} / \mathrm{kg}$ of $\mathrm{DM}$. 
in the DCAD (from 514 to $195 \mathrm{mEq} / \mathrm{kg}$ of DM) in the prepartum diet may be effective in increasing both feed intake and the availability of $\mathrm{Ca}$ and $\mathrm{P}$ at the onset of lactation, which is a period of great demand for $\mathrm{Ca}$ and P.

\section{Effect of Different K Concentrations in the Prepartum Diet on the Acid-Base Status of Periparturient Cows}

Changes in dietary $\mathrm{K}$ levels could modify the acidbase status of dry cows. A decline in urinary $\mathrm{pH}$ by decreasing dietary $\mathrm{K}$ levels, and hence a decrease in DCAD value, has been previously observed (Roche et al., 2002). In group $\mathrm{K}_{13}$, the significantly lower urinary $\mathrm{pH}$ and $\mathrm{NABE}$ values on $\mathrm{d} 3$ before parturition and the significantly lower BAQ during the last 2 wk before parturition clearly indicate a reduction of the alkalotic charge in the metabolism of the cows of this group. Despite lower values of $\mathrm{pH}$ and NABE for group $\mathrm{K}_{13}$ on $\mathrm{d} 14$ and 7 before parturition, it was only on $\mathrm{d} 3$ prepartum that a significant difference between the groups was evident. This was not the case for BAQ, which was significantly lower in group $\mathrm{K}_{13}$ during the entire prepartum period. In accordance with Bender and Staufenbiel (2003), who affirmed that BAQ seemed to be more representative than NABE because of the independence of the factor BAQ to diuresis (proportional ratio between base and acid), BAQ indicated in this study an earlier reduction of the metabolic alkalosis than did either $\mathrm{pH}$ or NABE. The decrease observed in $\mathrm{pH}, \mathrm{NABE}$, and $\mathrm{BAQ}$ as calving approached in group $\mathrm{K}_{13}$ could be related to the increasing proportion of concentrate feed in the diet, which resulted in lower DCAD values. However, in group $\mathrm{K}_{33}$, the DCAD decreased more than in group $\mathrm{K}_{13}$, but urinary $\mathrm{pH}$, NABE, and BAQ remained unchanged. The reasons for these inconsistent observations are unknown. In agreement with the results of $\mathrm{Hu}$ et al. (2007), blood pH and $\mathrm{HCO}_{3}{ }^{-}$concentration in both experimental groups remained stable. This showed that the reduction in the concentration of strong ions was insufficient to induce metabolic acidosis. The effect of the addition of anions to the prepartum diet to attain negative DCAD values and to alter the metabolic acid-base status has already been shown on several occasions (Block, 1984; Oetzel et al., 1988). The requirement for large amounts of anionic salts to sufficiently reduce the DCAD of forage-based diets to induce metabolic acidosis is almost impractical (Roche et al., 2002). An alternative would be the combination of a diet low in $\mathrm{K}$ with supplementation of anionic salts. Alternatives to sufficiently reduce DCAD require further research.

The results of the present study showed that even a moderate decrease in DCAD levels may cause some changes in the acid-base status of periparturient cows. These changes were detected earlier with $\mathrm{BAQ}$ than with $\mathrm{pH}$ or NABE. As observed by $\mathrm{Hu}$ et al. (2007), acid-base parameters in urine are more sensitive indicators of the acid-base status of cows than are blood parameters.

\section{CONCLUSIONS}

The results of this study indicate that the decrease in DCAD in positive ranges by feeding a low-K hay may provide positive benefits to the prepartum acid-base status and the mineral balance shortly after parturition in dairy cows. Decreasing DCAD from 514 to $195 \mathrm{mEq} /$ $\mathrm{kg}$ of DM induced a change in the prepartum acidbase homeostasis and reduced metabolic alkalosis, as indicated by reduced urinary $\mathrm{pH}, \mathrm{NABE}$, and BAQ. The BAQ indicator revealed this change earlier than did urinary $\mathrm{pH}$ or NABE and could prove to be a useful tool for early detection of changes in acid-base status in the periparturient cow. Feeding a low-K hay prepartum increased the daily feed intake during the first days after parturition and appeared to have a positive effect on the balance of $\mathrm{Ca}$ and $\mathrm{P}$ of dairy cows at the onset of lactation.

\section{REFERENCES}

Albin, R. C., and D. C. Clanton. 1966. Factors contributing to the variation in urinary creatinine and creatinine-nitrogen ratios in beef cattle. J. Anim. Sci. 25:107-112.

ALP. 2008. Fütterungsempfehlungen und Nährwerttabellen für Wiederkäuer. Online ed. Agroscope Liebefeld-Posieux Research Station ALP, Posieux, Switzerland. http://www.feed-alp.admin. ch/start.php?action=adv_search\&cmd=list_feed Accessed Oct. 7, 2008.

AOAC. 1995. Official Methods of Analysis. 16th ed. Assoc. Off. Anal. Chem., Arlington, VA.

Bender, S., and R. Staufenbiel. 2003. Methodical influence on selected parameters of the acid-base equilibrium in urine samples from dairy cows. [In German.] Berl. Munch. Tierarztl. Wochenschr. 116:432-435.

Block, E. 1984. Manipulating dietary anions and cations for prepartum dairy cows to reduce incidence of milk fever. J. Dairy Sci. 67:2939 2948.

Charbonneau, E., P. Y. Chouinard, G. F. Tremblay, G. Allard, and D. Pellerin. 2008. Hay to reduce dietary cation-anion difference for dry dairy cows. J. Dairy Sci. 91:1585-1596.

Charbonneau, E., D. Pellerin, and G. R. Oetzel. 2006. Impact of lowering dietary cation-anion difference in nonlactating dairy cows: A meta-analysis. J. Dairy Sci. 89:537-548.

Delaquis, A. M., and E. Block. 1995. Acid-base status, renal function, water, and macromineral metabolism of dry cows fed diets differing in cation-anion difference. J. Dairy Sci. 78:604-619.

Gaynor, P. J., F. J. Mueller, J. K. Miller, N. Ramsey, J. P. Goff, and R. L. Horst. 1989. Parturient hypocalcemia in Jersey cows fed alfalfa haylage-based diets with different cation to anion ratios. J. Dairy Sci. 72:2525-2531.

Goff, J. P. 2000. Pathophysiology of calcium and phosphorus disorders. Vet. Clin. North Am. Food Anim. Pract. 16:319-337.

Goff, J. P., and R. L. Horst. 1997. Effects of the addition of potassium or sodium, but not calcium, to prepartum ratios on milk fever in dairy cows. J. Dairy Sci. 80:176-186. 
Hu, W., M. R. Murphy, P. D. Constable, and E. Block. 2007. Dietary cation-anion difference effects on performance and acid-base status of dairy cows postpartum. J. Dairy Sci. 90:3367-3375.

Leiber, F., H. R. Wettsten, and M. Kreuzer. 2009. Is the intrinsic potassium content of forages an important factor in intake regulation of dairy cows? J. Anim. Physiol. Anim. Nutr. (Berl.) 93:391-399.

Liesegang, A., C. Chiappi, J. Risteli, J. Kessler, and H. D. Hess. 2007. Influence of different calcium contents in diets supplemented with anionic salts on bone metabolism in periparturient dairy cows. J. Anim. Physiol. Anim. Nutr. (Berl.) 91:120-129.

Martens, H., and M. Schweigel. 2000. Pathophysiology of grass tetany and other hypomagnesemias. Implications for clinical management. Vet. Clin. North Am. Food Anim. Pract. 16:339-368.

Mertens, D. R. 2002. Gravimetric determination of amylase-treated neutral detergent fiber in feeds with refluxing in beakers or crucibles: Collaborative study. J. AOAC Int. 85:1217-1240.

Oetzel, G. R., J. D. Olson, C. R. Curtis, and M. J. Fettman. 1988. Ammonium chloride and ammonium sulfate for prevention of parturient paresis in dairy cows. J. Dairy Sci. 71:3302-3309.
Roche, J. R., D. E. Dalley, P. Moate, C. Grainger, M. Hannah, F. O'Mara, and M. Rath. 2000. Variations in the dietary cation-anion difference and acid-base balance of dairy cows on a pasture-based diet in south-eastern Australia. Grass Forage Sci. 55:26-36.

Roche, J. R., J. Morton, and E. S. Kolver. 2002. Sulfur and chlorine play a non-acid base role in periparturient calcium homeostasis. J. Dairy Sci. 85:3444-3453.

Schonewille, J. T., A. T. Van't Klooster, H. Wouterse, and A. C. Beynen. 1997. Intrinsic potassium in grass silage and magnesium absorption in dry cows. Livest. Prod. Sci. 48:99-110.

Soder, K. J., and W. L. Stout. 2003. Effect of soil type and fertilization level on mineral concentration of pasture: Potential relationships to ruminant performance and health. J. Anim. Sci. 81:1603-1610.

Tucker, W. B., J. F. Hogue, G. D. Adams, M. Aslam, I. S. Shin, and G. Morgan. 1992. Influence of dietary cation-anion balance during the dry period on the occurrence of parturient paresis in cows fed excess calcium. J. Anim. Sci. 70:1238-1250.

Vagnoni, D. B., and G. R. Oetzel. 1998. Effects of dietary cationanion difference on the acid-base status of dry cows. J. Dairy Sci. 81:1643-1652. 